\title{
Alışveriş Merkezlerinin Göstergebilimsel Çözümlemesi
}

\author{
Halime Yücel BOURSE ${ }^{1 *}$
}

\section{ÖZ}

$\mathrm{Bu}$ çalışmada alışveriş merkezlerinin yapısı, biçimsel nitelikleri değerlendirilmiş, farklı bölümleri yer/yer-olmayan karşıtlığı doğrultusunda ele alınmıştır. Alışveriş merkezleri gibi tüketim alanlarının düzenlenmesi, yalnızca fiziksel niteliklerine göre değil, yaşam biçimi oluşumunun simgesel alanları gibi de değerlendirilebilir. Bu nedenle alışveriş merkezlerine yüklenen farklı değerler tanımlanmış, daha sonra alışveriş merkezi uzamıyla kent merkezi uzamının benzerlikleri ve farkıııkları tartışılmıştır.

Anahtar sözcükler: Alışveriş merkezi, göstergebilim, uzamın anlamı, tüketim değerleri.

\section{Malls' Semiotic Analysis}

\section{ABSTRACT}

In this work using a semiotic method we will analyze the structure of the shopping malls. First we will take into account the meaning created by the architectural structure of the shopping centers (the path organization, heights and sizes...). Second, we will analyze the structure of the shopping malls according to the opposition "places/non-places" while explaining the consumption values that they reflect. Lastly we will discuss oppositions and similarities between downtowns and shopping malls.

Keywords: Mall, semiotics, meaning of space, consommation values.

\section{GiRiş}

Günümüzde, özellikle büyük kentlerimizde beton ya da cam ağırlıklı, görkemli ya da küçük, değişik bir mimari tasarıma sahip ya da kişiliksiz alışveriş merkezleri dikkat çekici uzamlar oluşturmaktadır. Farklı toplumsal ve ekonomik düzeylerden farklı tüketiciler, farklı amaçlarla alışveriş merkezi deneyiminde bir araya gelmektedirler. Alışveriş merkezi bir ağın varlığı yardımıyla dolaşılabilecek bir yapıdır. İçindeki yollar, koridorlar dolaşım ağını, mağazalar da tecimsel iskeleti oluştur (Chivallon, Marme, Prost, 1998, s. 28). İlk alışveriş merkezleri Amerika Birleşik Devletleri'nde, XX. yüzyılın başında kurulmuştur. Avrupa'da alışveriş merkezlerinin gelişimi, otomobilin yaygınlaşması ve yol altyapısının gelişmesiyle hız kazanmıştır. Aynı zamanda Koehl'e göre (1990) kent merkezlerinin doygunluğa ulaşması, park yerlerinin azlığı, kent çevresinde nüfus artışı, tüketim biçimlerinin gelişimi, ürünlerin stoklanmasına izin veren farklı koşullar, alışveriş merkezlerinin gelişimini sağlamıştır. Alışveriş merkezi günümüzün kentsel dokusunun en önemli bileşenlerinden biri sayılabilir. Alışverişin küreselleşmesinin ve malların dolaşımı aracılığıyla kültürel göndergelerin uluslararasılaşmasının göstergesidir.

\footnotetext{
1 Galatasaray Üniversitesi İletişim Fakültesi yhalime@gmail.com *ilgili yazar / Corresponding author: yhalime@gmail.com

Gönderim Tarihi: 04.05.2017

Kabul Tarihi: 04.10.2017
} 
Alışveriş merkezi birçok mağazayı bir araya toplayarak daha çok müşteri çekmeyi sağlar. Sunumu canlandırmak için etkili bir strateji oluşturur (Lacour, 2009, s. 60). Bir alışveriş merkezinin hoşa gitmesi, çekici olması, geniş bir kesime seslenmesi önemlidir. Bu nedenle alışveriş merkezlerinin aralarında farklılıklar bulunsa da benzerlikler daha çoktur. Sermaye yarattığı düşler, toplumsal düzenin güvencesidir (Berdet, 2013, s. 8). İki yüzyılı aşkın bir zamandır, sermaye "malın iktidarı temeli üzerine kurulu, bireysel ve toplu zevkleri yönlendirmek amaçlı, ekonomik temellerini gizleyen yerler yaratıp durur. İnsanları körleştirmek için en iyi yol ışıldayarak gözleri kamaştırmaktır (Berdet, 2013, s. 61).

İnsanlar birbirlerinin görüntüleri ve davranışlarına göre, alışveriş merkezinin göstergelerini ve anlamlarını değerlendirirler (Harmon, 2005, s. 147). Kimi araştırmacılar için alışveriş merkezleri insan olma koşulunu en çok temsil eden uzamlardandır (Mattioli, 2011). Bu nedenle alışveriş merkezi uzamının göstergebilimsel bir incelemesi, toplum üzerine de kimi düşünceler geliştirmemizi sağlayabilir. Bu çalışmada da alışveriş merkezlerinin yapısı, biçimsel nitelikleri değerlendirilmiş, farklı bölümleri yer/yer-olmayan karşıtlığı doğrultusunda ele alınmıştır. Alışveriş merkezleri yaşam biçimi oluşumunun simgesel alanları gibi de değerlendirilebilir. Bu nedenle alışveriş merkezlerine yüklenen farklı değerler tanımlanmış, daha sonra da alışveriş merkezi uzamıyla kent merkezi uzamının benzerlikleri ve farklılıkları tartışılmıştır. Çalışmada söylemin ve anlatının çözümlenmesi için birçok model ortaya koyan Greimas'ın ve kurucusu olduğu Paris Okulu'nun anlatısal metinlerin incelenmesi için gönderge oluşturan göstergebilimsel dörtgeninden ve ikili karşıtlık ilkelerinden yararlanılmıştır (Greimas, 1983). Araştırma İstanbul'da bulunan Kanyon, Cevahir, Zorlu Center, İstinye Park, Akmerkez, City's, Trump Towers, Galleria, Carousel, Viaport ve Mall of İstanbul ve örneklerine dayanarak gerçekleştirilmiştir.

\section{ALIŞVERIŞ MERKEZLERININ BiçiMSEL ÖZELLIKLERI}

Kimi araştırmacılara göre alışveriş merkezi drama yaratmak, alışverişe gitme deneyimini artırmak için tasarlanmış ve güncellenmiştir (Donovan, Rossiter, 1982, s. 34-57; Kowinski: 1985). Alışveriş merkezi bir tiyatro gibidir, burada tüketiciler kendi evrenlerini yaratır, oyundaki rollerini düşlerler. Mağazacılar bunun için sahne, ışık ve mankenleri sağlarlar. Shields (1992, s. 3) alışveriş merkezinde alışveriş yapmayı film izlemeye, alışveriş merkezinin denetimli alanını da sinema salonuna benzetir.

Alışveriş merkezi göstergebilimiyse bu uzamı kutsal bir alan olarak kavramsallaştırır, çünkü dışarıya kapalı, geniş ve yüksektir (Massefoli, 1997). Dış evrenden korunaklıdır, içerisi denetimlidir. Birçok yazarca "tüketim katedralleri" diye nitelenmiştir (Ritzer, 2000, s. 15; Corrigan, 1997, s. 56; Kowinski, 1985, s. 218). Alışveriş merkezi ziyareti de kutsal bir yer ziyareti gibi kolektif coşku niteliği taşır (Andrieu, Badot, Macé, 2004, s. 56). İstek ekonomisiyle tüketim ekonomisi bu uzamda kesişir. Düzenlenme biçimi ve görsel yönlendirmeler, bir filmin planları gibi, alışverişçiyi yönlendirir. Koridorlar, yollar, yürüyen merdivenler, pencereler insanları bir oyuna sokar. Alışveriş merkezlerinin biçimsel özelliklerini dolaşım düzeni, büyüklükleri, yükseklik ve düzeyler açısından değerlendirebiliriz.

\subsection{Dolaşım düzeni}

Alışveriş merkezlerinin kimilerinde düz ve yalın bir dolaşım varken, kimileri, özellikle yeni alışveriş merkezleri biraz daha karmaşık, hafifçe dairesel dolaşım düzenlerine ağılık verirler. 
Alışveriş merkezlerinin atalarının pasajlar ve çarşılar olduğu söylenebilir (Lacour, 2009, s. 60). Buralar da insanın kendini özgür hissettiği kapalı yerlerdir (Massefoli 1997). İstanbul'da kurulan birçok alışveriş merkezi, özellikle ilk kurulanlar dolaşım düzeni açısından bu çarşılar ve pasajlar gibi daha düz, yalın bir mimari biçime uyarlar, genellikle doğrusal bir dolaşım düzeni benimserler. Galleria bunun bir örneğidir, ziyaretçilerine üçgen biçiminde bir dolaşım düzeni sunan Akmerkez de yenilikçiliğine karşın, bu mimari anlayışa uygundur. $\mathrm{Bu}$ yalınlık hem ziyaretçinin işini kolaylaştırır hem de daha kolay yönlendirilebilmesine olanak sağlar.

Alışveriş merkezlerinin dolaşım düzenleri arasında düz/dairesel karşıtlığı bulgulanabilir. Ritzer (2000, s. 15), alışveriş merkezi ziyaretlerini "hac" diye nitelendirir, alışveriş merkezlerine tüketim dinimizi uygulamak üzere hacca gittiğimizi söyler. Hac nitelemesinin nedeni belki de genellikle dairesel devinimlerle dönüp durmamızdır. Alışveriş merkezlerinde son dönemlerde kavisler yeğlenmeye başlanmış, öncesinin daha düz açıları terk edilmeye başlanmıştır. Kavis sıcak, düz çizgiyse katılıktır. Kavis yuvayı çağrıştırır, bir sahip olma, sığınma çağrısı vardır (Bachelard, 1957, s. 163). Kanyon, İstinye Park, Akasya, Cevahir gibi birçok alışveriş merkezi dairesel bir dolaşım düzeni sunarlar.

Alışveriş merkezlerinin dolaşım düzenleri arasında yalın/karmaşık karşıtlığı da saptanabilir. İlk alışveriş merkezleri yalın mimari ilkelere göre yapılmıştır, merkezcil ve kapalıdırlar, yapay aydınlatma vardır (Lacour, 2009, s. 60). Ancak günümüzde mimari tasarımıyla öne çıkan kimi alışveriş merkezlerinde ziyaretçiye doğrusal değil, daha karmaşık, kimi zaman labirenti düşündürebilecek yollar hazırlanır. Bu düzenleme dolaşmaya, aylaklığa yöneltir, birey yeni bir ritimle yeni keşiflerde bulunabilir. Zamanı iyi kullanabilmek, boşa zaman geçirmemek çağımızın niteliklerinden biriyken alışveriş merkezlerinin labirent düşüncesini bulması ilginçtir. Uzam böylece zamansal baskıyı da sınırlar. Bu düzenlemeler de tüketiciler tarafından değişik bulunur, beğenilir. Ancak bu düzenin işleyebilmesi, tüketici için sorun yaratmaması için geniş, boş alanların da bulunması gerekir (Daucé, 2000, s. 81). Örneğin Zorlu ve Kanyon, kıvrımlı, dairesel dolaşım düzenleri içerirler, "8" biçiminde, dolaşana daha doğal gelebilecek düzenlerdir bunlar. Bu durum gezenin yolunu uzatıp zorlaştırsa da dolaşmayı mekanik olmaktan biraz da olsa uzaklaştırır. Kanyon'da arka koridorlar az da olsa bir dolaşım seçeneği sunar. Ayrıca Cevahir alışveriş merkezi ve İstinye Park bir orta bölüm/arka bölüm içerirler, ancak izlenebilecek yollar açısından seçenek sunmazlar, yalnızca arka bölümlerde dolaşmak olanaksızdır, kısa koridorlar orta bölüme bağlanır. Köşeler düşsel ve uçucu da olsa bir mahremiyet izlenimi verirler (Bachelard, 1957, s. 163) Alışveriş merkezlerinde de böyle köşeler bulunabilir. Kimi zaman daha pahalı mağazalar köşelere yakın konumlanır ya da Cevahir'de olduğu gibi, masa sandalye konularak insanların dinlenmesi için bir ortam yaratılır. Ritzer alışveriş merkezlerinde de tapınakların merkezlilik, simetri ve düzen unsurlarının bulunduğunu belirtir (2000, s. 27). Dolayısıyla alışveriş merkezlerindeki dolaşım düzeninin karmaşıklığı da ölçülüdür, ziyaretçinin işi çok da zorlaştırılmaz.

\subsection{Yükseklik}

Yüksek/alçak karşıtlığı da İstanbul alışveriş merkezleri arasında belirginleşmeye başlamıştır. İlk alışveriş merkezleri hem geniş hem de yüksektir. Akmerkez, Cevahir gibi alışveriş merkezleri buna örnektir. Son dönemlerde Metrocity, Kanyon, İstinye Park gibi birçok alışveriş merkezi bunun tersine dışarıdan alçak yapılar gibi görünür, yüksek değil, "derin"dirler. Ancak Astoria, Saphir, Trump Towers gibi alışveriş merkezleri, içerdikleri iş 
merkezleri ve konutlarla göğe yükselirler. Viaport ise daha çok bir kasaba gibidir, bireyler açık havada, iki yanında mağazaların bulunduğu temiz, düzenli, araçların geçmediği yapay sokaklarda gezebilirler.

Alışveriş merkezlerinin kendi içinde de yukarısı/aşağısı karşıtlığı saptanabilir. Yukarısı/aşağısı karşıtlığı kimi zaman lüks mağaza/sıradan mağaza karşıtlığına denk düşebilir. Elbette "sıradan" ya da "lüks" görecelidir, alışveriş merkezinin niteliğine göre değişir. Kanyon, İstinye Park ya da Zorlu Center'da sıradan sayılan bir marka, bir başka alışveriş merkezi için lüks sayılabilir. Kimi alışveriş merkezlerinde üst katlara çıkıldıkça daha pahalı mağazaların bulunması, kutsallık benzetimiyle açıklanabilir. Araştırmacıların alışveriş merkezinin tapınağa, kutsal uzamlara benzediği düşüncesi göz önüne alınırsa, üst katların daha pahalı, ulaşılması daha zor, bir bakıma daha "kutsal" markalara uygun görüldüğü düşünülebilir. Bachelard, "yukarı uzam doruğun uzamıdır, aşağı uzamsa tersine, çamurun, sabitliğin uzamıdır", der (1957, s. 173). Genellikle alışveriş merkezinin en alt katında da hemen kurtulunmak istenen otopark bulunur.

Alışveriş merkezlerinin iç düzenlenişinde de lüks mağazalar ve daha orta düzey mağazalar arasında bir karşıtlık görülebilir. Örneğin lüks mağazaların vitrinleri çoğunlukla içerisi görünmeyecek biçimde düzenlenir. Girişler göreceli olarak küçük olabilir. Bu mağazalardan alışveriş yapamayacak kişilerin cesaretini kırabilecek biçimde düzenlenmişlerdir. Elbette mağazalara girmek sokaktakinden daha kolaydır, ancak toplumsal farklılıkların duyumsanmasına da önem verilir. Daha ulaşılabilir mağazalarınsa girişleri geniştir, olabildiğince çok kişinin içeri girebilmesi istenir. Buralara insanlar rahat biçimde girebilir, kendilerini daha az denetim ve gözetim altında duyumsarlar. İstinye Park ve Zorlu Center'da lüks mağazaların bir bölümü, alışveriş merkezinin dış bölümünde, açık ya da yarı-açık alandadır. Böylece başka bir yere girildiği, ortak alana ilişkin olmadıkları izlenimi uyanır. İstinye Park'taki lüks mağazaların içeride olanları da en orta bölümde değil, köşelere yakın konumlandırımıştır.

Alışveriş merkezlerinde katların ya da alanlarının düzenlenişini de Floch'un hipermarket incelemesinden yararlanarak da açıklayabiliriz (Floch, 1989, s. 37-89). Buna göre alışveriş merkezlerinde kullanımsal alanlar, eğlensel alanlar, yararsal alanlar ve varoluşsal alanlar ayırt edilebilir. Örneğin alt katlar daha çok kullanımsal alana ayrılır, genellikle terzi, lostracı hizmetleri, biraz yukarısında da market bulunur. Böylece tüketici isterse gereksinimlerini hızlıca karşılayabilir. Kimi alışveriş merkezlerinde, Akmerkez ve Cevahir'de olduğu gibi bankalar, beyaz eşya mağazaları da alt katlardadır. Varoluşsal alanda giyim mağazaları, şık lokantalar, kafeler vardır. Eğlensel alan daha çok oyun bölümünü, hediyelik eşya mağazalarını, "fast food" lokantaları, süslü, ışıklı alanları kapsar. Özellikle yılbaşı etkinlikleri döneminde, çoğu alışveriş merkezinin orta bölümlerinin buna göre düzenlendiği gözlemlenebilir. Yararsal alansa danışma, otopark ödeme noktaları ya da çekilişlere katılmak için başvurulan stantlardır.

Genellikle alışveriş merkezlerinde kullanımsal alanlar alt katlarda bulunurken, varoluşsal alanlara üst katlara çıkıldıkça ulaşılır. Ancak kimi alışveriş merkezlerinde mağazaların ender rastlandığı üst katlar ya da alt katlar "fast food" yemeklere ve oyunlara ayrılır, örneğin Cevahir, Akmerkez, Carousel, Profilo gibi daha geleneksel düzenlere sahip alışveriş merkezleri böyledir. Cevahir'de en alt katta çok geniş bir oyun alanı da bulunur. Böyle durumlarda görece şık lokanta ve kafeler mağazaların arasında yer alır (Lacour, 2009, s. 249). Yiyecek alışverişi daha pratiktir, düz yollar, koridorlar vardır. Haz alışverişi için erişim biraz daha karmaşıktır. 


\subsection{Büyüklük}

Alışveriş merkezleri için önemli göstergelerden biri de büyüklüktür. Yaşamımızı ev, ofis gibi daha sınırlı ve küçük uzamlarda geçirdiğimizden, alışveriş merkezinin büyüklüğü bizim için etkileyici ve çekicidir. Örneğin Cevahir alışveriş merkezi açılmadan, reklamı büyüklüğü üzerinde durularak yapılmıştır. Planlayıcılar bu nedenle alışveriş merkezlerini olduğundan büyük gösterme amacını güdebilirler (Ritzer, 2000, s. 204). Ancak günümüzde büyüklüğün yanı sıra, belirli bir hedef kitleye seslenmek de önem taşır. Zorlu Center ya da Kanyon alışveriş merkezinin özellikleri boyutlarıyla değil, yer verdiği pahalı mağaza ve lokantalarla belirginleşir. Ayrıca birçok kişinin büyük ve yorucu bir alandansa istediklerini bulabilecekleri, kendilerine biçtikleri yaşam biçimine uygun bir alışveriş merkezini yeğleyecekleri düşünülebilir. Ama örneğin Mall of İstanbul çok daha geniş bir kitleye seslenme amacını güttüğünden, büyüklüğü önem taşır.

Alışveriş merkezi sokağa benzeyen galerileriyle küçük bir kent gibidir. Genellikle alışveriş merkezlerini içeriden kent gibi değerlendirmemizin nedeni, alışveriş merkezi kullanıcısı olmamızdır. Alışveriş merkezine girdiğimizde, açılış kapanış saatleriyle, iç uzamlarıyla alışveriş merkezi mantığına uyarız. Orası hem bir nesne hem bir üst-nesne hem bir uzam, hem de bir ortamdır (Shields, 1994, s. 203-229).

\section{ALIŞVERIŞ MERKEZININ YER/YER-OLMAYAN AYRIMININ BAĞLAMINDA YAPISI}

Marc Augé alışveriş merkezlerini yer-olmayan diye sınıflandırır (1992). Yer, uzamın belirli, genel ve soyut bir biçimde değerlendirilen bir parçasıdır. Augé bu kavramla yer-olmayan kavramını birkaç ölçüte göre karşıtlaştırır. Yazara göre bir yer kimliksel, tarihsel ve ilişkiseldir. Kimliksel, tarihsel ya da ilişkisel olmayan uzam bir yer-olmayandır (1992, s. 100). Yer-olmayanlar insanların ve nesnelerin hızlı dolaşımı için gerekli alanlardır. Yerolmayan tanımı, çağdaş toplumların, içinde zaman geçirilen, ama benimsenemeyen havaalanları, otoyollar, mülteci kampları, alışveriş merkezleri gibi önemli uzamlarını içerir (1992, s. 48). Augé'ye göre alışveriş merkezlerinde birey kendini yalnız ve tanınmayan bir kişi gibi duyumsar, sessizce dolaşır, ödemesini kredi kartıyla yapar, otomobilini otoparktan alır, otomat da ona iyi yolculuklar diler. Dolayısıyla insan ilişkilerinin sınırlı olduğu, kişiselleştiremeyeceğimiz uzamlardır. Gerçekten de alışveriş merkezlerinde, aynı alanda kapalı bulunan insanların birbirlerine yakınlık duyup iletişim kurmaları pek beklenmez. Belki belirli açılardan kent merkezinden olduğundan daha rahattırlar. Herkes birbirini izler, ancak göz temasından kaçınılır. Bu ilişkisellik azlığı birçok kişi için elverişli bir durum da sayılabilir.

Augé'nin yaklaşımı alışveriş merkezi konusunda bir gönderge niteliği taşır. Ancak yer/yerolmayan karşıtlığı belki de alışveriş merkezleri açısından derecelendirilerek göreceli bir biçimde ele alınmalıdır. Her alışveriş merkezi aynı yer-olmayan nitelikleri taşımayabilir. Örneğin Kanyon, birçok büyük alışveriş merkezine göre, daha çok benimsenen, biraz daha ilişkisel olabilen bir alışveriş merkezidir. Belki de yarı-açık olması onu "yarı-yer" durumuna getirir. Alışveriş merkezleri tarihsel bir kimlikten yoksun sayılırlar, ancak ilerleyen dönemlerde kendilerine özgü bir tarihin oluşacağını düşünebiliriz.

Ele alınması gereken bir başka konuysa bir alışveriş merkezi içinde de yer/yer-olmayan karşıtlıklarının bulunabileceğidir. Alışveriş merkezinin her bölümü aynı niteliklere sahip 
değildir: bir dış yer-olmayan, bir iç yer-olmayan ve yerlerin bulunduğu gözlemlenebilir. Tüm bu farklı alanlar, niteliklerini açıklayabilecek biçimde göstergelerle donatılmıştır.

\subsection{Dış yer-olmayan}

Alışveriş merkezlerinin dış alanları genellikle yalındır, her şey alışveriş merkezine ulaşmak için yapılmıştır. Renkler yalın, genellikle gridir, endüstriyel kent yapısıyla uyum gösterir. Kimi zaman, İstinye Park'taki gibi, alışveriş merkezinin duvarlarında içerideki refah evrenini çağrıştıracak görseller kullanılabilir ya da Akmerkez'in yılbaşı süslemelerinde görüldüğü gibi dönemsel olarak süslenebilir. Dışarıdaki kişi bu görüntüleri görse de bir yerolmayandadır ya caddede bir aracın içindedir ya da dışarıda kaldırımdadır, çok gösterişli olmayan, gri, yalın, kimi zaman kalabalık, pek sevimli sayılamayacak bir alandadır.

\section{2. İç yer-olmayan}

Dış yer-olmayandaki kişi, alışveriş merkezine aracıyla girerse, iç yer-olmayandan geçmek zorundadır. İç uzamda en belirgin yer-olmayan otoparktır. Bir denetimden sonra otoparka ulaşabilir. Otopark oldukça loş, gerekli göstergeler dışında renksiz, dışarıda yer almadığı sürece de havasız bir alandır. Alışveriş merkezinin iç uzamıyla büyük bir karşıtlık içindedir. Ancak otoparktan alışveriş merkezine girildiğinde de hemen yere ulaşılmaz. Kimi zaman yine bir denetimden sonra, ışığın genellikle beyaz ve bol olduğu, güzel mağazalardan çok, çerçeveci, kunduracı, terzi gibi hizmetlerin önerildiği bir alana gelinir. Tüm bunları aşınca daha yumuşak ışıklı ve renkli bir evrene girebilir. Yaya ziyaretçi içinse iç yer-olmayanın aşılması daha kolaydır, kapıdan, gerekirse de denetimden geçmesi yere ulaşmasına yeter.

\subsection{Yer}

Alışveriş merkezinin mağazalarının, kafelerinin, lokantalarının bulunduğu alanlar yerlerdir.

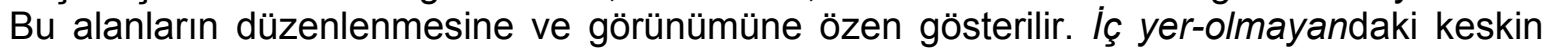
ışığa karşılık, burada yumuşak, rahatsız etmeyen bir ışık vardır. Ancak genellikle zemin, temizlik ve modernlik çağrışımı yapacak biçimde parlaktır. Yer-olmayan alanlardaki gibi gri değil, mağazaların vitrinleri, kafe ve lokantaların dekorasyonları nedeniyle renklidir. Bu farklılıkları şöyle ortaya koyabiliriz:

\begin{tabular}{|l|l|l|l|}
\hline Yer & Yumuşak ışık & Canlı renkler & Çok renklilik \\
\hline Yer-olmayan & Parlak ışık & Yalın renkler & Benzer renkler \\
\hline
\end{tabular}

Alışveriş merkezindeki yer-olmayanlar ve yerler farklı davranış biçimleri yaratırlar. Ziyaretçi yer-olmayan alanları çabucak geçme eğilimindedir. Amacı belirlidir, otoparktaysa otomobilini park etmesi, yayaysa döner kapıdan ve denetimden geçmesi gerekir, oyalanmaz. İç yer-olmayandaysa yalnızca gereklilikler doğrultusunda zaman harcayabilir, dolaşmaz, fazla zaman geçirmesi çevresindekilerce tuhaf karşılanabilir. Ancak yere ulaştığında rahatlar, çevresine bakınmaya başlar, daha yavaş yürüyebilir, tüm gününü alışveriş merkezinde geçirebilir. İnsan ilişkilerinin de yer-olmayan ve yer arasında farklılaştığı açıktır. Yer-olmayanda insan ilişkileri sınırlıdır, kimi zaman, denetim söz konusu değilse, ziyaretçi de iç yer-olmayan alanda bulunan hizmetleri alma ya da çevresindekilere yolunu sorma gereği duymuyorsa, otopark ödemesini de otomatik olarak gerçekleştiriyorsa hiç insan ilişkisi yoktur. Oysa yerde, mağaza çalışanlarıyla, lokanta ve kafelerde garsonlarla konuşabilir. Çevresindeki kişilere görüş sorması, kimi zaman sohbet 
etmesi de olağandır. Tanıdıklarıyla buluşup zaman geçirmesi için de uygun bir ortam vardır. Bu açılardan alışveriş merkezlerinin düzenlenişinin insan ilişkilerini de biçimlendirdiği öne sürülebilir.

Özetlemek gerekirse alışveriş merkezinin yer/yer-olmayan alanları arasında şu karşıtlıklar gözlemlenebilir:

\begin{tabular}{|l|l|}
\hline Yer & Yer olmayan \\
\hline Fazla düzenlenmemiş alan & Düzenlenmiş alan \\
\hline Geniş alan & Kısıtlı alan \\
\hline Hızlı devinim & Orta-yavaş devinim \\
\hline Toplumsal etkileşim yokluğu & Toplumsal etkileşim varlığı \\
\hline Bireysel kamusal alan & Kolektif alan \\
\hline
\end{tabular}

Çizelge 2: Yer/Yer-olmayan karşıtııları

Bu saptamalardan yola çıkarak günümüzde alışveriş merkezlerinin tümüyle bir yerolmayan gibi değerlendirilemeyeceği, en azından yarı-yer sayılması gerektiği düşünülebilir. Zaten Marc Augé de yer-olmayanın saf biçimiyle var olmadığını, burada da ilişkilerin kurulabileceğini belirtir: "yer ve yer-olmayan değişken kutuplardır. İlki hiçbir zaman tümüyle silinmez, ikincisiyse hiçbir zaman tümüyle belirmez" (Augé, 1992, s. 101). Elbette alışveriş merkezini tümüyle kişiselleştirmek, burada iz bırakmak, sokaktakinden daha zordur. Ancak alışveriş merkezlerini yer-olmayan, ruhsuz alanlar gibi tanımlamak her zaman doğru değildir. Kimi durumlarda kaçış alanı oluşturabilirler, insanlar buralarda toplanıp etkileşimde bulunabilirler. Kişisel ilişki kurmak açısından sokaktakinden daha az sakınımlı davranabilirler. Alışveriş merkezlerini kişisellikten, toplumsallıktan, politikadan arınmış ruhsuz uzamlar gibi görmek, biraz da ahlakçı bir bakış açısının ürünüdür.

\subsection{Güdük toplumsallaşma}

Marc Augé'nin alışveriş merkezlerini yer-olmayanlar diye nitelendirip toplumsallaşmanın, toplumsal ilişkinin bulunmadığı uzamlar olarak değerlendirmesine karşın, bu uzamlarda belirli bir toplumsal etkileşimin gerçekleştiği yadsınamaz. İnsanların toplandığı yerlerdir, belirli bir toplumsal işlevlerinin bulunduğunu kabul etmek gerekir. Sinemaya, tiyatroya gidilebilen alışveriş merkezlerinin sayısı çoktur, yemek ve içmek gibi etkinlikler de toplumsallaşmayı kolaylaştırır.

Günümüzde gençler alışveriş merkezlerinde buluşabilmekte, anne babalar çocuklarını gezdirmeye alışveriş merkezine götürmektedirler. Bunun dışında toplumsal ilişkilerden uzaklaşan yaşlı insanlar için de alışveriş merkezlerinin bir toplumsal ortam sağladığı düşünülebilir. Alışveriş merkezi gençler için olduğu kadar yaşlılar için de bir toplumsallaşma alanıdır. Özellikle kent merkezi dışındaki alanlarda belirli bir toplumsallık eksikliğini bir ölçüde giderebilirler. Kent dışındaki yerleşim alanlarını canlandırır, bir kimlik sağlar, yalıtılmayı ve yabancılaşmayı bir ölçüde engeller (Berdet, 2013).

Ancak alışveriş merkezi toplumsallığı bir kent meydanındaki toplumsallaşmadan biraz daha farklıdır, güdük bir toplumsallıktır. Her toplumsal sınıfa, her toplumsal olaya açık değildir. Çünkü tam anlamıyla kamusal değil, özel alandır. Alışveriş merkezindeki toplumsal ilişkilerin çoğunluğu da tecime yöneliktir. Satış ya da hizmet görevlileriyle ilişkiler, ne kadar dostça olsalar da böyledir. Para harcamadan zaman geçirildiğindeyse, 
Alışveriş Merkezlerinin Göstergebilimsel Çözümlemesi

Malls' Semiotic Analysis

para harcayan insanlar ve para harcama olanakları gözlemlenir. Arkadaşlarla buluşulduğu zamanlarda da mağazaları gezme olasılığı, kent merkezinde, sokakta buluşulduğu zamankinden daha yüksektir. Alışveriş merkezinin mantığı, tecimin mantığı, önerdiği toplumsallaşma da tecim mantığının ağırlık kazandığı güdük bir toplumsallaşmadır.

\section{ALIŞVERIŞ MERKEZLERININ ZIYARETÇILERINE SUNDUKLARI DEĞERLER}

Alışveriş merkezleri çoğu kez "tüketim katedralleri" diye nitelendirilirler, ancak öne çıkan yalnızca tüketim değil, tüketim gösterisidir. Tüketim evreni birçokları için neşelidir, yapay bir enerji ve mutluluk verir. Buna tanıklık etmek, gösteriyi izlemek de tüketim evrenine belirli bir katılım sağlar. Işıltılı, renkli, güzel düzenlenmiş vitrinler, buralardan alışveriş eden kişiler, belirli bir gösteri ve esenlik evreni yaratırlar.

Rob Shields (1992) alışveriş merkezinin iletişim ve toplumsal etkileşim açısından öneminin malların dağıtımındaki ekonomik işlevini gölgelediğini belirtir. Alışveriş merkezine yalnızca gerekli bir ürünü almaya değil, görülmek, yaşam biçimi alışverişi yoluyla tüketim kültürünün göstergelerini içselleştirmek için de gidilir. Yaşam biçimi alışverişi bir kültürel devrim sayılır. Özel ve kamusal, sanat ve yaşam, boş zaman ve tüketim arasında, kültür ve ekonomi arasında deneyim alanları yaratır. Alışveriş bir ilişki deneyimidir, ailelerle, arkadaşlarla, yeni tanıdıklarla ilişki kurmayı kolaylaştırabilir. Kamusal alanın anlamı ve işlevi insanın yaşam biçimindeki, algılamasındaki değişimleri gösterir. Modaya ve kültürel farklılıklara kayıtsız evrensel insan, yerini tüketim gösterisini izleyen insana bırakmıştır.

Benjamin'in Dünya Fuarları konusunda yazdıkları alışveriş merkezleri üzerine eleştirinin temellerinden birini oluşturur: "Dünya fuarları malın değiştirme değerini çarpıtır. Kullanım değerinin arka plana itildiği bir çerçeve yaratır. İnsanın zaman geçirmek için içerisine daldığı bir düşsel evreni oluşturur. Eğlence endüstrisi de insanı malın eriştiği düzeye yükselterek, bu fantazmagoriye girmesini kolaylaştırır. İnsanoğlu da kendine ve başkalarına yabancılaşmasının tadını çıkararak, kendini böyle bir dünyanın yönlendirmesine bırakmış olur" (Benjamin, 1993, s. 83). Alışveriş merkezi ziyaretçileri için de benzer durumların geçerli olduğunu düşünebiliriz. Yönlendirme konusunda da alışveriş merkezi dünya fuarlarından aşağı kalmaz, düzenlenmesi, iç mimarisi ziyaretçiyi yönlendirir. Bireyler buraya yalnızca satın almak için değil, eğlenmek, bunun da ötesinde kendilerini başka bir evrende gibi duyumsamak için giderler. Alışveriş merkezi yalnızca gerekliliğe indirgenemez (Massefoli, 1997).

Alışveriş merkezlerinin ziyaretçileri için yaratılan değerleri, Jean-Marie Floch'un tüketim değerleri sınıflandırması yardımıyla açıklayabiliriz. Jean-Marie Floch, Algirdas Julien Greimas ve Paris Okulu'nun göstergebilimini uygulayarak reklamın ve pazarlama çalışmalarının sunduğu tüketim değerlerini bulgulayıp, göstergebilimsel dörtgen aracılığıyla görselleştirir. Değer nesnelerinin ikili anlambilimsel boyutları bulunduğunu hem kullanım değerini hem de söylensel ya da varoluşsal değerini içerdiklerini saptar. Varoluşsal değer, tüketicinin öznel kimliği ve toplumsal konumunun anlatımıyla bağıntılıdır. Tüketim değerlerinin göstergebilimsel dörtgeninde, kullanımsal değerlerle temel değerler ya da varoluşsal değerler karşıtlık eksenini, eğlence gibi kullanımsal olmayan değerler ya da eğlensel değerlerle, varoluşsal olmayan değerler ya da yararsal değerler alt-karşıtlık eksenini oluştururlar. Ayrıca kullanımsal değerler ve yararsal değerler ile varoluşsal değerler ve eğlensel değerler bütünleyicilik ekseninde yer alırlar (Floch, 1990, s. 199). 


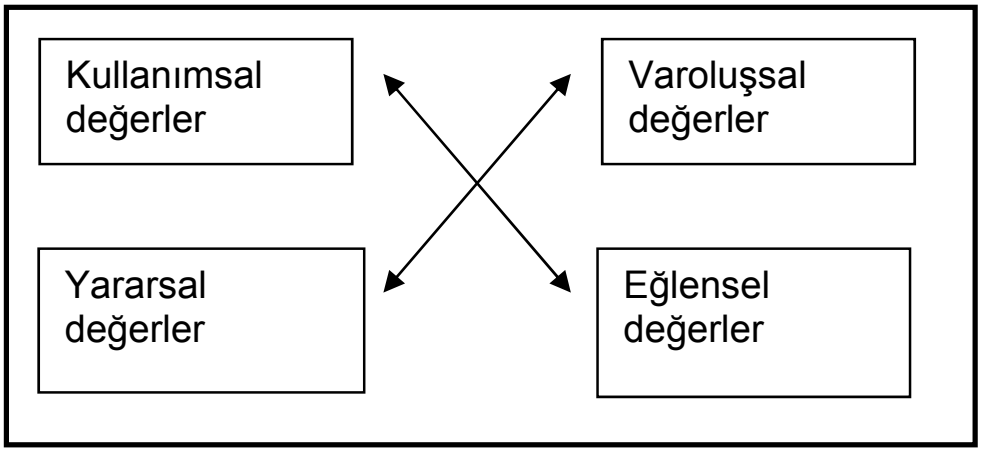

Çizelge 3: Tüketim değerleri göstergebilimsel dörtgeni

Alışveriş merkezlerinin kullanımını da varoluşsal değerler, kullanımsal değerler, eğlensel değerler ve yararsal değerlerle açıklayabiliriz.

\subsection{Kullanımsal değerler}

Alışveriş merkezi tüketicilere, birçok mağazayı bir arada bulundurarak kolaylık sağlar. Tüketici seçenekleri fazla yorulmadan değerlendirebilir, gereksinimlerini sokaktakinden daha rahat karşılar. Üstelik birçok alışveriş merkezinin bir hipermarket içermesi, yiyecek içecek gereksinimlerini de aynı zaman diliminde karşılamasını sağlar. Ayrıca alışveriş merkezi olumsuz hava koşullarından koruyarak tüketicinin soğuk, sıcak ya da yağışlı havadan olumsuz etkilenmemesini sağlar. Genelde yorulduğunda oturabileceği banklar da bulunur. Böylece tüketici bir şey içmek ya da yemek, kısacası para harcamak zorunda kalmadan alışveriş arasında dinlenebilir.

\subsection{Eğlensel değerler}

Elbette alışveriş yalnızca gereklilikten gerçekleştirilen bir edim değildir, zevk için alışveriş yapabilen birçok tüketici de vardır. Ayrıca alışveriş merkezinin eğlensel değerlerini tüketebilmek için yalnızca alışveriş yapmak gerekmez, bir şey yiyip içmek ya da yalnızca mağazalara, vitrinlere bakmak da yeterli olabilir. Birçok alışveriş merkezi, mağaza ve lokantaların yanı sıra eğlence olanağı sağlayacak uzamlar da içerir. Örneğin Cevahir alışveriş merkezinde büyük bir oyun ve eğlence salonu vardır, Profilo alışveriş merkezinde bowling salonu bulunur, Carousel'de atlıkarınca, kimi alışveriş merkezlerinde küçük buz pateni sahaları da vardır, çoğu oldukça rahat sinema salonlarıyla donanmıştır. Alışveriş merkezlerinde eğlence aratacak küçük etkinlikler de düzenlenir. Özellikle hafta sonları, minik konserlere, yarışmalar, palyaçolara sık rastlanır. İşletmeciler eğlencenin alışveriş merkezi için ne kadar önemli olduğunu anlamışlardır. Düzenlenen eğlenceler, mağazaların da gelirini artııır. Ancak alışveriş merkezlerindeki bu alanlar tecimi düşündürmemelidir (Mattioli, 2011).

Kent dışında kurulan alışveriş merkezleri kent merkeziyle rekabetten çok, küçük merkezler yaratarak, belki de bu yerleşim birimlerinin merkezleşmesine, "yaşam alanı" durumuna gelmesine katkıda bulunur. Böylece kent dışında yaşayan, kimi durumlarda işe gitmek için her gün uzun yolculuklar yapmak zorunda kalan kişiler, en azından alışveriş ve eğlence istediklerinde kendi bölgelerinde kalabilirler. Bu durumda alışveriş merkezleri de sundukları olanaklarla boş zamanları geçirmeye elverişli uzamlardır. 


\subsection{Yararsal değerler}

Sezon sonu ürünleri satan alışveriş merkezleri, eğlensel değerlerin yanı sıra, yararsal değerler de sunar. Bu alışveriş merkezleri, eğlence ve yemek olanakları açısından ötekilerden fazla geride kalmaz. Çünkü yalnızca yararsal değer sunumu bireyleri alışveriş merkezine yöneltmeyi sağlamaz. Ürünleri indirimli almayı sağlayabilecek daha farklı alışveriş ortamları da vardır. Örneğin internetten alışverişin yaygınlaşması ve daha hesaplı duruma gelmesiyle alışveriş merkezlerinin ziyaretçi yitimine uğrayabileceği öngörülebilir. Amerika Birleşik Devletleri'nde yapılan bir araştırma, alışveriş merkezlerinin giderek boşaldığını gösterir (Merrick, 2014). Türkiye'de birbiri ardına açılan alışveriş merkezleri, ülkemizde böyle bir tehlike olmadığının kanıtı gibi değerlendirilebilse de alışveriş merkezlerinin maldan daha fazlasını, bir yaşam biçimini sunması, ürünlerin ötesinde göstergelerle donanması gerekir. Tüketici buraya haz verici, ödüllendirici deneyimler yaşamak için gider (Tauber, 1972, s. 46-59).

\subsection{Varoluşsal değerler}

Alışveriş merkezleri kimi niteliklerine göre az ya da çok varoluşsal değer sunabilir. Birçok alışveriş merkezi, özellikle "lüks" olarak nitelendirilenler, bir yaşam biçimi önerme savındadır. Günümüzde Kanyon ve Zorlu Center'ın böyle bir işlevi bulunduğu söylenebilir. $\mathrm{Bu}$ uzamlara gitmenin belirli bir toplumsal değer sunduğu, insanı belirli bir varsıllık ve toplumsal saygınlık durumunda duyumsattığı düşünülebilir. Bu alışveriş merkezlerinin marketler bölümleri bile tüketicinin kullanımsal değerlerin ötesine geçmesine, lüks gibi değerlerle, kendini toplumsal açıdan iyi bir konumda görmeye katkıda bulunabilir. Kimi alışveriş merkezleri aynı zamanda konutları da içerdiğinden tam anlamıyla bir yaşam biçimi sundukları söylenebilir. Elbette tüketicilerden çok az bir bölümü bu konutlarda oturma şansına ulaşabilse de bu durum alışveriş merkezli yaşam biçimine özenmelerini engellemez. Lüks alışveriş merkezlerinde gezinmek bile, hiçbir ürün satın alınmasa da kimileri için belirli bir düzey göstergesi olabilir, "kaliteli" bir yere gidildiğini düşündürebilir. Lüks alışveriş merkezlerine gidenler "görülme" isteği içinde, görünüşlerine biraz daha çok özen gösterirler. Ayrıca insanlar alışveriş merkezi kültürüne katılmak için her zaman para harcamak zorunda değillerdir, tüketim gösterisini izlemekle de yetinebilirler.

Mağazaları dolaşmak tüketici için bir değer kaynağıdır (Bloch, Ridgway, Dawson, 1994, s. 23-42). Alışveriş merkezi birey tarafından bir gösteri gibi kabul edilir (Belk; Bryce, 1993). Birey burada insanların yinelenen tüketim hazzının çoğalması yoluyla bir topluluk arayışındadır. Alışveriş merkezi ziyareti belirli bir röntgenciliğe ve umutsuz gençlik isteğine karşılık gelir. Oswald'ın belirttiği gibi, alışveriş merkezi kültüründe görmek ve görülmek önemlidir. Alışveriş de görmek, görülmek, nesnelere simgesel anlamda sahip olmak arasında bir gerilim içerir (Oswald, 1996, s. 49). Yalnızca alışveriş değil, simgesel değiş tokuş da yapılır. Alışveriş merkezi ortamı hazcı tüketim etkinliğinin bir parçasıdır (Langrehr, 1991).

\section{ALIŞVERIŞ MERKEZi/KENT MERKEZI KARŞITLIĞI}

Alışveriş merkezleriyle kent merkezleri çoğu kez karşıtlaştırılır. İnsanlar önceleri kent merkezlerinde zaman geçirmeyi, tecimsel ve kültürel etkinliklerde bulunmayı yeğlerken günümüzde alışveriş merkezlerinin de zaman geçirilen, buluşulan, kültürel etkinliklerde bulunulan uzamlar durumuna geldiği gözlemlenebilir. Elbette kent merkezlerinin de boşaldığı söylenemez, özellikle İstanbul gibi nüfus yoğunluğu fazla olan bir kentte, kent 
merkezlerinin boşalması oldukça güçtür.

Alışveriş merkezleri kent merkezinde de kent çevresinde de olsa, René Péron'un belirttiği gibi, kent ve tecim arasındaki bir ayrım mantığına dayanır: satış aygıtının kent dokusuna göre özerkleşmesidir (Péron,1993). İç düzenlenmesi sokak modeline dayanır (Chivallon, Marme, Prost, 1998, s. 32). Mağazaların vitrinleri iç/dış eklemlenmesini, banklar, bitkiler, kafe ve lokantaların terasları, kiosklar, sokak/dış uzam öykünümünü güçlendirir. Alışveriş merkezi kentten parçaları alıp biraraya getirir. Kimi zaman palmiye gibi dekor öğeleriyle egzotiklik izlenimi de yaratılır. Danışma, hizmet noktaları, müzik, aydınlatma düzeni, uzamın düzenlenişi gibi öğeleriyle sokaktan daha yumuşak bir hava vardır.

\subsection{Doğal/Yapay}

Kent merkezleri ve sokaklar alışveriş merkezleriyle karşıtlaştırılsa da alışveriş merkezlerinin bir bölümünde bu karşıtlaşmayı azaltmak, arınık, yapay ve tarihsiz değil, otantik görünmek için bir çaba sezilebilir. Köşe başındaki küçük lokanta ya da pazar yeri gibi estetik girişimlerle alışveriş merkezleri sokağa öykünür. Örneğin oldukça dar, biraz da loş, dolayısıyla kapanma duygusunu belirgin bir biçimde uyandıran City's'in üst katında bir "Mahalle" yaratıımıştır. Ne kadar inandırıcılıktan uzak olsa da bir çarşı yerinin özellikleri bu "mahallede" canlandırılmaya çalışılır. Burada ilginç olan, City's'in kent dışında değil, zaten belirli bir mahalle yaşamının bulunduğu Nişantaşı'nda yer almasıdır. Dolayısıyla semt sakinlerinin herhangi bir özlemine karşılık gelmez. Üstelik gerçek bir mahalleden daha dar, daha havasızdır. City's'in "Mahalle"sinin işlevi çelişkin, neredeyse ironiktir. İnsanları mahalleden koparıp alışveriş merkezine kapatır, dışarıda kalan mahallenin bir öykünümünü içeride yaratır. Ancak buradaki toplumsal ilişkiler elbette gerçek bir mahallede olabileceğinden farklıdır. İnsanlar genellikle birbirlerini tanımazlar, mahallenin önemli bir niteliği olan mahalle sakinleri burada gelip geçicidir, yapay mahalleye karşı da duyarsızdırlar, onu sahiplenemezler. İstinye Park'taki pazar alanıysa bu benzetiminin düzenlenmesi açısından daha başarılı sayılır. Trump Towers alışveriş merkezinin "Cadde"si de benzer bir yaklaşımın ürünüdür. Trump Towers'in terasındaki "Cadde", alışveriş merkezi müdavimlerinin kent özlemini "kente inmelerine" gerek bırakmadan gidermeye yönelir. Açık havada bulunmasıyla City'sin mahallesinden daha gerçeğe yakın bulunabilse de çelişkinlik açısından geride kalmaz: "Cadde", doğal ve özgür bir görüntü sağladığı düşünülebilecek grafitilerle süslenmiştir. Gerçekte sokak sanatının bir türünü oluşturan, yasaklanan doğası gereği başkaldırma düşüncesini içeren grafiti, "Cadde"de denetimli bir biçimde, yabancı grafiti sanatçılarının yardımıyla dekorasyon öğesi olarak yerleştirilmiştir. Dolayısıyla yalnızca "Cadde" oluşumu değil, "Cadde"nin grafitileri de özleriyle çelişirler. Yine de ziyaretçilerde doğallık, özgürlük izlenimlerini uyandırdıkları ileri sürülebilir. Örnekleri çoğaltılabilecek bu tür yaklaşımlar, alışveriş merkezlerinin tecimsel ağırlıklı niteliğini biraz örterek, doğal bir hava kazandırmayı amaçlar.

Benjamin (1993, s. 230) "caddeler toplumun konutudur" der. Bireylerin kendi dört duvarları içinde yaşadıklarını ve öğrendiklerini, toplumun da binaların dış duvarları arasında yaşadığını, öğrendiğini ve düşündüğünü belirtir. Üzerinde "afiş yapıştırmak yasaktır" yazılı duvarların, toplum için yazı yazabileceği yerler gibi algılandığını yazar. Elbette alışveriş merkezinin "caddeleri", gerçek caddenin tam tersidir. İnsanlar yasaklara uymak zorundadırlar, gerçek bir caddede olabileceğinden çok daha fazla denetim vardır. Cadde ya da sokak "dışarısı", alışveriş merkezi ise "içerisi"dir. Cadde, toplum tarafından değişime uğratılabilir, alışveriş merkeziyse yöneticilerinin belirlediği kurallara uyar. Dışarısıliçerisi 
karşıtlığı, değiştirilebilen/değiştirilemeyen karşıtlığına karşılık gelir.

Sokak/alışveriş merkezi arasında doku karşıtlıkları da saptanabilir. Sokak daha tozlu ve mattır, alışveriş merkezlerindeyse genellikle yüzeyler temiz ve parlaktır. Kimilerinin binalarının dış yüzeyleri de parlak ve cam ağırlıklı olabilmektedir. Bu durum alışveriş merkezini doğallıktan uzaklaştırır. Ayrıca alışveriş merkezlerine biraz daha sözde doğallık kazandırmak amacıyla bitki, havuz, çakıl taşı gibi dekorasyon malzemeleri kullanılır. Ayrıca genellikle alışveriş merkezi tecimsel olmayan bir gösteri öğesi içerir. Amaç, alışveriş merkezinin yalnızca yalın ürünü düşündürmemesi, bir boş zaman etkinliği, insanları mala yöneltebilecek farklı nedenler sunmasıdır.

\subsection{Farklılık/Benzerlik}

Kenti, semtleri, sokakları gezerken aradığımız farklılıktır, birbirinin aynısı sokakları değil, kendi özellikleri, farklılıkları bulunan, kendilerine özgü çarşısı, dükkânları olan yerlere gitmeyi yeğleriz. Alışveriş merkezleri konusunda da farklılıklar kadar benzerlikler de önemlidir. Birçoğunda aynı mağazalar bulunur, insanlar ne bulacaklarını bilirler. Ritzer'e göre alışveriş merkezlerinin verimliliği de buna bağlıdır. Mağaza zincirleri olmasa alışveriş merkezleri varlığını sürdüremez. Mağaza zincirleriyle alışveriş merkezleri birbirini besler, aynı zamanda alışveriş merkezlerinin çoğunun birbirine benzemesine yol açar (Ritzer, 1998, s. 63). Alışveriş merkezlerinde farklı mağazalar olması kadar, aynı mağazaların olması da önemlidir. İnsanlar bildikleri mağazalara girmekten, alıştıklarını yapmaktan da hoşlanırlar. Serüven, kavram olarak çekici gelse de insanların çoğunun güvenlik ve tekdüzelik aradıklarını söyleyebiliriz.

Kendi aralarında büyük farklılıkları da olsa genel bir alışveriş merkezi ortamının varlığından söz edilebilir. Yerel kültürler öne çıkarılmaz, farklı ülkelerde, farklı büyüklükte de olsa, farklı mağazalar ve lokantalar içerse de alışveriş merkezlerinin genel ortamları açısından birbirine benzediği söylenebilir. Oysa sokak değişken kimlikli, yerel izler taşıyan bir uzamdır.

\subsection{Güven/Serüven}

Bireylerin kendilerini alışveriş merkezlerinde güvende duyumsadıklarını düşünebiliriz. Yarıaçık alışveriş merkezleri bile dışarıdan, sokaktan çok daha korunaklıdır. İnsanların peşine takılarak sözle rahatsız etme olaylarına sokaktaki kadar sık rastlanmaz. Çocuklarını tek başına sokağa bırakamayanlar, alışveriş merkezine daha rahat bırakabilirler. Tuvaletlerin olması bile belirli bir güven sağlar. Oysa sokakta hava koşulları ve insanların davranışları daha az öngörülebilirdir. Bu nedenle sokağın küçük de olsa sorunlara yol açabileceği, oysa alışveriş merkezlerinin güven sağladığını ileri sürebiliriz. Böylece sokak ve alışveriş merkezi arasında güven/güvensizlik, kimi zaman da güven/tehlike karşıtlıkları kurulur. Elbette bu karşıtlıkların çoğu kez yapay olduğunu da düşünebiliriz. Alışveriş merkezleri yaygınlaştıkça, bu uzamların güvenli, bilinen, sokaklarınsa güvensiz, bilinmeyen olduğuna ilişkin düşünce de artabilir. Çünkü alışveriş merkezlerine öncelik veren bir kent kültürü ortaya çıkmaya başlar.

Alışveriş merkezinin kötü havalara ve kentsel şiddete karşı bir "ilkyardım mimarisi" oluşturduğu da ileri sürülmüştür (Freitas, 1996). Böylece trafik sorununun ve hava kirliliğinin olmadığı bir ülküsel çağdaş kent oluşturur. Alışveriş merkezi/kent merkezi karşıtlığı bir bakıma yaşamın "arınık" anlayışına da gönderme yapar. Kent merkezlerinin 
tehlikeli ve pis, alışveriş merkezlerininse temiz ve güvenli olduğunu sezdirir.

\subsection{Kültür/Ticaret}

Kültürün ve tarihin belirginleştiği kentsel alanlar yerine, alışveriş merkezlerinin çoğalmasıyla ekonomik güç göstergeleri önem kazanmıştır. Alışveriş merkezlerinin büyüklüğü, belirli bölgelerde yoğunlaşmaları ekonomik gücün göstergesi durumuna gelmiştir. Alışveriş merkezleri kentin ekonomi merkezli bir anlayışına göndermede bulunur. Monnet'ye göre, şirketlerin karar makamlarının bulunduğu bölgeler, ekonomik merkezselliği oluşturur (2000, s. 401). İstanbul'da da Mecidiyeköy, Gayrettepe, Levent, 4. Levent gibi bölgelerde alışveriş merkezlerinin yoğunlaştığı gözlemlenebilir.

İstanbul'da ilk alışveriş merkezleri 1990'ların başında, kent merkezinde değil, daha çok orta-üst gelir düzeyinden kişilerin oturduğu, Bakırköy ve Etiler gibi semtlerde açılmıştır. Ancak artık kent anlayışının değiştiğini ve alışveriş merkezinin kentin başlıca öğelerinden biri durumuna geldiğini söyleyebiliriz. Taksim İstiklal Caddesi ve Nişantaşı gibi mağazaların eksik olmadığı toplumsal kent merkezlerinde de alışveriş merkezlerinin açılması, yeni kent anlayışının kültürelden uzaklaşıp ticariye yöneldiğini gösterir.

Kentlerin ekinsel, toplumsal, tecimsel, erişilebilirlik, ekonomik merkezsellik gibi birçok merkezselliği bulunduğunu belirten Monnet'ye göre, çağdaş kentlerin düzenlenmesinin eski şeması, kent merkezinin dışındaki alışveriş merkezi olgusuyla karşıtlaşır. Bu durum bir merkez-çevre ilişkisini tersine çevirir. Kültürel bir merkezsellik yerine, ticari merkezsellik yaratır. Erişilebilirlik merkezselliği de (Monnet, 2000, s. 401) ticari merkezsellikle bağıntılıdır. Aslında alışveriş merkezlerinin de küçük kentler gibi tasarlandığı düşünülebilir. Özellikle konutları olan alışveriş merkezleri bu anlayışa uygun sayılır. Ancak bunların dışında kent merkezinin sunabileceği olanakları, daha rahat ve güvenli bir biçimde insanlara sunarlar. Buradaki sorun, alışveriş merkezlerinin kent merkezlerine oranla kişiliksiz olmasıdır. Ancak Kanyon gibi kimi alışveriş merkezleri bu sorunu aşmış ve belirli bir kimliğe, estetiğe ulaşmış gibidirler.

\section{5. İçerisi/Dışarısı}

Içerisi/dışarısı karşıtlığı, yalnız alışveriş merkezleri açısından değil, uzamın söz konusu olduğu her durum için önemli bir karşıtlıktır. Bachelard felsefecilerin bunu olmak/olmamak karşıtlığına benzettiklerini, biçimsel karşıtlığın ötesinde, bir yabancılaşma, bir düşmanlık gördüklerini dile getirir (1957, s.238). Alışveriş merkezlerinde de bu karşıtlığın belirgin olduğu, çevrelerinden özenle ayrıldıkları söylenebilir.

Walt Disney'in 1955'te Disneyland için söyledikleri, alışveriş merkezleri için de geçerlidir: "Halkın yaşadıkları gerçek evreni, parktayken görmesini istemiyorum. Kendilerini başka bir evrende gibi duyumsamalarını istiyorum". Disneyland'in düzenlenmesi bir yalıtım ilkesine dayanır, içerisi dışarıdan, dışarısı da içeriden görülmemelidir. Alışveriş merkezlerinin de içi genellikle dışarıdan görülmez, içeridekiler de dışarıyı pek görmezler, gördüklerindeyse Cevahir ve Zorlu Center'ın lokantalarında olduğu gibi, bir kent görünümü gibi izlerler. Louis Marin Disneyland çözümlemesinde, parka girmek için yapılan güvenlik aşamalarını Disneyland'i cennet adasıyla özdeşleştirmek için kullanır, güvenlikten geçişi, Sırat köprüsünde geçişe benzetir. Alışveriş merkezlerinde de kimi açılardan buna benzer bir durum söz konusudur. Disneyland'deki kadar belirgin olmasa da insanların kendilerini bir 
Alışveriş Merkezlerinin Göstergebilimsel Çözümlemesi

Malls' Semiotic Analysis

başka evrende gibi duyumsamaları istendiği düşünülebilir. Elbette "içerisi" Disneyland gibi fantastik değildir, ancak birçok açıdan "dışarısından" farklılaşır. Güvenlikten geçtikten sonra, rahat, yazın serin, kışın sıcak bir ortama girilir.

Kent merkeziyle alışveriş merkezinde aynı mağazalar olsa da farklıdırlar. Kent merkezi açıktır, birçok sokak üst-merkeze doğru yönlendirir. Alışveriş merkezi simgesel düzeyde kapalıdır, birkaç girişten erişilir, merkezcil bir yerdir, duvarlar ya da farklı engellerle özdekselleştirilir. Duvarlar, tehdit edici düzensizliğe karşı uzamı korur. Eşikten geçildikten sonra kopuşlar içeren farklı evrene girilir.

Alışveriş merkezinin mantığı, kapanma mantığına uyar, sınırları belirlidir. Teraslar ve yarıaçık alanlar bile iç uzamda yapay bir dışsallık içerir (Chivallan, Marme, 1998, s. 33). Günümüzde yeğlenen yarı-açık alışveriş merkezlerinde de dışarıyı görmek oldukça zordur. Bu uzamlarda içeride olduğu kadar dışarıda da mağazalar ve lokantalar bulunur, ayrıcalıklı bir sokak görünümü oluşur. Ayrıca alışveriş merkezinin güvenlikli ve denetim altında olması, ziyaretçinin tüketim ve eğlence evrenine dalmasını kolaylaştırır. "Alışveriş merkezi ruhu" diye nitelendirebileceğimiz, tüketim, eğlence ve güdük bir toplumsallaşma durumuna erişebilmek için, zaman ve para kısıtlılıklarıyla bizi baskılayan gündelik yaşamdan kopmamız, en azından uzaklaşmamız gerekir. Bu da dışarıdan kopuk, kendine özgü bir zaman düzeni bulunan bir uzamda daha kolaydır.

Marc Augé'nin alışveriş merkezlerini yer-olmayan diye nitelendirmesi, alışveriş merkezi ile kent merkezini karşıtlaştıran bir yaklaşımdır. Ancak her açıdan doğru değildir. Elbette alışveriş merkezinin belirli bir tarihsel anlamdan yoksun olduğu düşünülebilir, bu da onu genellikle tarihsel ve kültürel anlamlarda donanmış kent merkezinden farklılaştırır. Ancak alışveriş merkezlerinde de kişilerin bireysel tarihinin oluşmaya başladığı düşünülebilir. Alışveriş merkezinin kamusal alanın temel bileşenlerinden biri durumuna gelme olasılığı tartışılır. Ancak sokağın yerine geçemez, çünkü alışveriş merkezi ticarete dayalıdır, uzam, sokakta olabileceği gibi benimsenmez, düşünce dile getirilemez. Alışveriş merkezleri çok denetimli, gözetim altında, kurallı, kapalı uzamlardır. Zaman kavramını da ortadan kaldırır. Genellikle 10.00-22.00 saatleri arası açık olsalar da içerisi hep aydınlıktır. İnsanlar alışveriş merkezine zaman ve uzamı parantez içine almak amacıyla gidebilirler. Aslında alışveriş merkezleri sokağın tüm sıradan halkına açık sayılmaz. İnsanların kent merkezindeki özgürlüğü yoktur. Ancak bu durum vitrin bakma özgürlüğüyle telafi edilir. Ama kentin bir fragmanı bile değildir, çünkü kent pratiği alışverişe indirgenemez

Kent çevresindeki alışveriş merkezleri, kentlileri çevreye çeker, kent merkezinde oturanlar bile, kimi zaman boş zamanlarında kentten uzaklaşarak bu alışveriş merkezlerine giderler. Böylece alışveriş merkezleri çelişkin bir biçimde kent çevresini bir ölçüde merkezleştirir, kent merkezineyse bir çevre havası kazandırır. Kent çevresindeki yapılaşmayla kendini gösteren yeni kent düzeni de kentlileri çevreye çekmeyi amaçlar.

\section{DEĞERLENDIRME VE SONUÇ}

Alışveriş merkezleri, günümüzün kent dokusunun önemli öğelerindendir. Ancak kendilerine özgü işleyişleri ve kurallarıyla, dış evrenden korunaklı oluşlarıyla sokağın uzamından farklılaşırlar. Alışveriş deneyimini kolaylaştırmak, hatta bir anlatıya dönüştürmek üzere tasarlanmışlardır. Dolaşım düzeni, yükseklik, büyüklük gibi biçimsel nitelikleri ve ortaya koydukları tüketim değerleri de bu anlatıya katkıda bulunur. Alışveriş merkezlerini sokağın 
uzamından farklı kılan en önemli özelliklerinden biri de zamansal işleyişleridir. Açılış/kapanış saatleri, gündüz/gece ayrımından daha belirgindir. Alışveriş merkezi yarı açık değil de tümüyle kapalıysa kullanılan aydınlatma, içinde bulunulan zaman dilimi konusunda bir ipucu vermez. Herkese açık görünür, ancak onu hem yalıtan hem de erişilebilir kılan bir açılma ve kapanma düzeni vardır. Alışveriş merkezleri herkese açık demokratik uzamlar gibi tanıtılsa da en azından İstanbul'da çoğuna güvenlik denetiminden sonra geçilir. Herkes içeri alınmaz, kapıları hem erişilebilirliği hem de engelleri düşündürür. Birbirleriyle uyuşmayan birçok yeri tek bir gerçek uzamda buluşturur, beton/doğa, kamusal/özel gibi bölümleri bir araya getirir.

Alışveriş merkezi, sokakla karşıtlaşmakla birlikte, sokak üzerine söylem üretir. Cadde'ler, Mahalle'ler, alışveriş merkezi merkezinde kurulmuş sözde semt pazarları, doğaya öykünen iç uzamlar bunun örneğidir. Alışveriş merkezi doğaya da övündüğü cadde, mahalle ya da semt pazarına da karşıttır, ancak bunları içinde barındırdığı yanılsamasını yaratmaya çalışır. Bolluk ve refah düşüncelerini yansıtır, ancak bu kavramlar da alışveriş merkezlerinde karşıtlıklarıyla var olurlar. Ürünler boldur elbette, ancak toplum tam anlamıyla refah içinde bulunmadığından, onları alamayan kişiler de vardır. Alışveriş merkezi bir yaşam biçimi yansıtır, ancak çoğu kişi için, izlenebilmesine karşın herkes için ulaşılamayan, özenilen, eleştirilen bir yaşam biçimidir bu. Temiz, parlak, havadar alışveriş merkezinde çoğu kişi kendini geçici olarak iyi hissedebilir, ama yansıttığı yaşama her zaman erişemez, özenmekle ya da eleştirmekle yetinir.

\section{KAYNAKÇA}

Andrieu, Françoise; Badot Olivier, Macé, Sandrine, "Le West Edmonton Mall: un échafaudage sensoriel au service d'une cosmogonie populaire?". Revue française du marketing, 196 (1/5), 2004, s. 3-66.

Augé, Marc, Non-Lieux. Introduction a une anthropologie de la sur modernité, Seuil, Paris 1992.

Bachelard, Gaston, La poétique de l'espace, http://www.philo-online.com, (Erişim tarihi: 07.02.2017, saat12.45.

Belk, Russel ve Bryce, Wendy, "Christmas shopping scenes: from modern miracle to postmodern mall", International Journal of Research in Marketing, 10, 1993, s. 277-296.

Benjamin, Walter, Pasajlar, Çev. Ahmet Cemal, Yapı Kredi, İstanbul 1993.

Berdet, Marc, Fantasmagories du capital- L'invention de la ville marchandise, Zones, Paris 2013.

Bloch, Peter H.; Ridgway, Nancy M.; Dawson Scott A., "The shopping Mall as a Consumer Habitat", Journal of Retailing, 70,1994, s. 23-42.

Chivallon, Christine; Marme, Nathalie; Prost Dominique, "Artefact de lieu et urbanité", Annales de la recherche urbaine,78, 1998, s. 28-37.

Corrigan, Peter, The Sociology of Consumption, Sage, Londra 1997. 
Daucé, Bruno, La diffusion de senteurs d'ambiance dans un ieu commercial: intérêts et tests des effets sur le comportement, École Doctorale de Sciences Économiques et de Gestion de l'Université de Rennes 1, Rennes 2000.

Donovan, Robert; Rossiter, John, "Store Atmosphere: An Environmental Psychology Approach”, Journal of Retailing, 58: 1982, s. 34-57.

Floch, Jean-Marie, "La contribution d'une sémiotique structurale a la conception d'un hypermarché”, Recherche et applications en Marketing, (2/89), 1989, s. 37-89.

Floch, Jean-Marie, Sémiotique, marketing et communication, PUF, Paris 1990.

Freitas, Ricardo Ferreira, Centres commerciaux: lles urbaines de la post-modernité, L'Harmattan, Paris 1996.

Harmon, Tracy R., "The Meaning Behind Marketing: Semiotic Oriented Research in Marketing and Consumer Research, The Future of Marketing Past". Proceedings of the 12th Conference on Historical Analysis and Research in Marketing (CHARM), 12, Long Beach, 2005, s.144-150.

Koehl, Jean-Luc, Les centres commerciaux, PUF, Paris 1990.

Kowinski, William Severini, The Malling of America: An inside look at the great consumer paradise, William Morrow and co, New York 1985.

Lacour, Jean-Pierre, "Observation ethologique du consommateur dans une grande surface d'article de sport”, Revue française du marketing, 4/199, 2004, s.39-48.

Lacour, Jean-Pierre, Circuit de magasinage dans un centre commercial d'hypermarché, Université Jean Moulin Lyon 3, Lyon 2009.

Marin, Louis, "Disneyland, a Degenerate Utopia", Johns Hopkins Textual Studies, Johns Hopkins Univ. Press, Baltimore, 1977, s. 50-66.

Massefoli, Michel, Du nomadisme. Vagabondages initiatique, Biblio, Paris 1997.

Mattioli, Fabio "Dimensions politiques et relations sociales dans les centres commerciaux". Cités Territoires Gouvernance. http://base.citego.info/fr/corpus_analyse/fiche-analyse50.html. (Erişim tarihi: 04.12.2016, saat: 8:30).

Merrick, Amy, "Are malls over?". http://www.newyorker.com/online/blogs/currency/2014/03/are-malls-over.html. (Erişim tarihi: 14.11.2016, saat: 10:50).

Michaud-Trevinal, Aurélia, "Le shopping dans un centre commercial: typologie de parcours et expérience vécue", 13ème Colloque E. Thil, La Rochelle 2010.

Monnet, Jérôme, "Les dimensions symboliques de la centralité", Cahiers de Géographie du Québec, 44/123, Québec 2000, s. 399-418. 
Oswald, Laura R., "The Place and Space of Consumption in a Material World", Marketing Semiotics, 12, 1996, s. 48-62.

Péron, René, "Le près et le proche les formes recomposées de la proximité commerciale", Les annales de la recherche urbaine, 78, 1993.

Ritzer, George, Toplumun McDonaldlaştırılması. Çağdaş Toplum Yaşamının Değişen Karakteri Üzerine Bir İnceleme, Çev., Şen Süer Kaya, Ayrıntı Yayınları, İstanbul 1998.

Ritzer, George, Büyüsü Bozulmuş Dünyayı Büyülemek, Çev., Şen Süer Kaya. Ayrıntı Yayınları, İstanbul 2000.

Shields, Rob, Lifestyle Shopping: the Subject of Consumption, Routledge, Londra, 1992.

Shields, Rob "The Logic of the Mall", The Socialness of Things: Essays on the SocioSemiotics of Objects, Stephen Harold Riggins (der.) içinde, Mouton de Gruyter, New York 1994.

Tauber, Edward M., "Why do people shop?", Journal of Marketing, 4/36: 197, 2, s.46-59. 